\title{
In vitro effect photodynamic therapy with differents photosensitizers on cariogenic microorganisms
}

\author{
P. Soria-Lozano ${ }^{1}$, Y. Gilaberte ${ }^{2,3}$, MP Paz-Cristobal ${ }^{3}$, L. Pérez-Artiaga ${ }^{3}$, V. Lampaya-Pérez ${ }^{3}$, J. Aporta ${ }^{4}$, \\ V. Pérez-Laguna ${ }^{3}$, I. García-Luque ${ }^{5}$, MJ Revillo ${ }^{1}$ and A. Rezusta ${ }^{1,3,6^{*}}$
}

\begin{abstract}
Background: Antimicrobial photodynamic therapy has been proposed as an alternative to suppress subgingival species. This results from the balance among Streptococcus sanguis, Streptococcus mutans and Candida albicans in the dental biofilm. Not all the photosensitizers have the same photodynamic effect against the different microorganims. The objective of this study is to compare in vitro the photodynamic effect of methylene blue (MB), rose Bengal (RB) and curcumin (CUR) in combination with white light on the cariogenic microorganism S. mutans, S. sanguis and C. albicans.

Results: Photodynamic therapy with MB, RB and CUR inhibited $6 \log 10$ the growth of both bacteria but at different concentrations: $0.31-0.62 \mu \mathrm{g} / \mathrm{ml}$ and $0.62-1.25 \mu \mathrm{g} / \mathrm{ml} \mathrm{RB}$ were needed to photoinactivate S. mutans and S. sanguis, respectively; $1.25-2.5 \mu \mathrm{g} / \mathrm{ml} \mathrm{MB}$ for both species; whereas higher CUR concentrations $(80-160 \mu \mathrm{g} / \mathrm{ml}$ and $160-320 \mathrm{\mu g} / \mathrm{ml}$ ) were required to obtain the same reduction in S. mutans and S. sanguis viability respectively. The minimal fungicidal concentration of MB for $5 \log 10$ CFU reduction (4.5 McFarland) was 80-160 $\mu \mathrm{g} / \mathrm{ml}$, whereas for RB it ranged between 320 and $640 \mu \mathrm{g} / \mathrm{ml}$. For CUR, even the maximum studied concentration $(1280 \mu \mathrm{g} / \mathrm{ml})$ did not reach that inhibition. Incubation time had no effect in all experiments.

Conclusions: Photodynamic therapy with RB, MB and CUR and white light is effective in killing S. mutans and S. sanguis strains, although $\mathrm{MB}$ and $\mathrm{RB}$ are more efficient than CUR. C. albicans required higher concentrations of all photosensitizers to obtain a fungicidal effect, being MB the most efficient and CUR ineffective.
\end{abstract}

\section{Background}

The human oral cavity is colonized by a highly diverse community of bacteria [1]. Dental caries is a chronic, invasive disease involving demineralization of the tooth followed by destruction of the organic phase of the dentine [2] and it is the consequence of the interaction between oral microflora, diet, dentition and oral environment [3].

Streptococci are the main colonizers of oral surfaces and constitute $70 \%$ of the cultivable bacteria existing in the human dental plaque [4]. In fact, S. mutans is the most prevalent microorganism of the plaque and the

\footnotetext{
*Correspondence: arezusta@unizar.es

'Department of Microbiology, Hospital Universitario Miguel Servet, Zaragoza, Spain

${ }^{3}$ Health Science Institute of Aragón, Zaragoza, Spain

Full list of author information is available at the end of the article
}

primary pathogenic agent responsible for caries disease [5], whereas S. sanguis is thought to play a benign, if not a beneficial, role in the oral cavity [6]. On the other hand, C. albicans is a commensal fungal species commonly colonizing human mucosal surfaces [7]. Falsetta et al. [8] hypothesize that $S$. mutans-C. albicans association may enhance $S$. mutans infection and modulate the development of hypervirulent biofilms on tooth surfaces, which will in turn influence the onset and severity of dental caries in vivo. For this reason, S. mutans, S. sanguis and $C$. albicans should be included in any study about human dental plaque microorganisms.

Photodynamic therapy (PDT) has been advocated as an alternative to antimicrobial agents to suppress subgingival species [9] due to the extensive and inappropriate use of antimicrobial agents which gradually led to the development of pervasive resistance [10]. Antimicrobial PDT

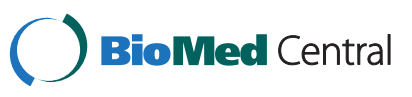

(c) 2015 Soria-Lozano et al. Open Access This article is distributed under the terms of the Creative Commons Attribution 4.0 International License (http://creativecommons.org/licenses/by/4.0/), which permits unrestricted use, distribution, and reproduction in any medium, provided you give appropriate credit to the original author(s) and the source, provide a link to the Creative Commons license, and indicate if changes were made. The Creative Commons Public Domain Dedication waiver (http://creativecommons.org/publicdomain/zero/1.0/) applies to the data made available in this article, unless otherwise stated. 
(aPDT) is a technique that utilizes reactive oxygen species (ROS) produced by non-toxic dye or photosensitizer (PS) molecules in the presence of low intensity visible light to kill mammalian or microbial cells [11]. Due to this mechanism, It is hypothesized that bacteria will not be easily able to develop resistance to PDT [12].

More than 400 compounds with photosensitizing properties are known, including dyes, drugs, chemicals and many natural substances [13]. Methylene blue (MB), a well-known dye with high light absorption at $665 \mathrm{~nm}$, is effective in aPDT, showing ability to kill not only Gram positive and Gram negative bacteria but also fungi [14-17]. Rose Bengal (RB) is a xanthene dye characterized by light absorption at wavelengths $(\lambda)$ of $450-600 \mathrm{~nm}$, used for the diagnosis of eye diseases [18]. From an antimicrobial point of view, RB has shown a good profile to photoinactivate microorganisms [19-22]. Curcumin (CUR) is an intensely yellow pigment, isolated from rhizomes of Curcuma longa, with a peak of light absorption at $430 \mathrm{~nm}$ [23]. Among its many biological activities are its anti-carcinogenic, antioxidant, antiinflammatory, antimicrobial properties and its hypoglycemic effects in humans [24, 25]. Some studies have shown its capacity to effectively photoinactivate in vitro C. albicans $[26,27]$.

There are many papers exploring the aPDT effect of different photosensitizers (PSs) in almost all kind of microbial species [28-31]. However, only few of them compare the efficacy of several photosensitizers on different microorganism [32].

The aim of this study was to compare the photoinactivation effect of three PSs, MB, RB and CUR, on S. mutans, S. sanguis and C. albicans.

\section{Results}

\section{Photoinactivation of bacterial suspensions}

Under the experimental conditions, PDT with MB, RB and CUR inhibited $6 \log 10$ the growth of both strains of bacteria reaching a bactericidal effect. However, less concentration of RB than of the other PSs was needed to kill Streptococcus spp. Whereas this bactericidal effect was achieved for $S$. mutans with a concentration of $\mathrm{RB}$ as low as $0.31-0.62 \mu \mathrm{g} / \mathrm{ml}$, higher $\mathrm{MB}$ concentration $(1.25-2.5 \mu \mathrm{g} / \mathrm{ml})$ was needed to reach the same reduction. In the case of $S$. sanguis, the RB and MB concentrations needed to obtain the same bactericidal effect were quite similar to those used for S.mutans $(0.62-1.25 \mu \mathrm{g} / \mathrm{ml}$ and $1.25-2.5 \mu \mathrm{g} / \mathrm{ml}$, respectively). Much higher concentrations of CUR were necessary to obtain the same reduction either for S. mutans or S. sanguis (Table 1).

Regarding the effect of the incubation time of Streptococcus cells with the PSs, one hour halved the minimal concentration of $\mathrm{MB}$ or $\mathrm{RB}$ necessary to attain $6 \log 10$ reduction respect to an incubation time lower than
1 min ( $<1 \mathrm{~min}$ ), especially for $S$. sanguis (Table 1$)$. In the case of CUR, this effect was only observed for S. sanguis. Not significant additional benefit was achieved using $3 \mathrm{~h}$ of incubation (Table 1).

Comparing the photodynamic effect of $\mathrm{MB}$ for $S$. mutans and $S$. sanguis suspensions, using the optimal incubation for each PS, lower concentrations were needed to reach the bactericidal effect for $S$. sanguis than for $S$. mutans (Fig. 1). However, no differences were observed using RB as PS.

\section{Photoinactivation of $C$. albicans}

Table 1 shows the minimum fungicidal concentration (MFC) of each PS starting from C. albicans 4.5 McFarland. Under the experimental conditions, PDT with $\mathrm{MB}, \mathrm{RB}$ but not with CUR inhibited $5 \log 10$ the growth of $C$. albicans, being the needed concentrations of $\mathrm{MB}$ smaller than the RB ones (Fig. 2). An increase in the incubation time with the PS was only beneficial for $\mathrm{MB}$, because $3 \mathrm{~h}$ halved the concentration needed to reach a $5 \log 10$ reduction in C. albicans respect to shorter times (Table 1).

\section{Discussion}

Dental caries may be a disease well suited to PDT [2]. Our investigation showed that PDT using MB or RB and a white lamp can kill cariogenic microorganisms, such as $S$. mutans, S. sanguis and C. albicans. In contrast, even though PDT with CUR reaches the same bactericidal effect, much higher concentrations were needed and it was not effective against yeasts.

PDT efficacy depends on the microorganism, the PS and the light used. According to our results, RB showed higher antimicrobial photodynamic effect for

Table 1 Minimal range concentration to reduce $6 \log 10$ of S. mutans and S. sanguis and $5 \log 10$ of C. albicans

\begin{tabular}{llll}
\hline $\begin{array}{l}\text { Pre-irradiation } \\
\text { Incubation time (h) }\end{array}$ & RB & CUR \\
\hline S. mutans ATCC 35668 & & \\
$<1 \mathrm{~min}$ & $1.25-2.5 \mu \mathrm{g} / \mathrm{ml}$ & $0.31-0.62 \mu \mathrm{g} / \mathrm{ml}$ & $80-160 \mu \mathrm{g} / \mathrm{ml}$ \\
$1 \mathrm{~h}$ & $0.62-1.25 \mu \mathrm{g} / \mathrm{ml}$ & $0.15-0.31 \mu \mathrm{g} / \mathrm{ml}$ & $160-320 \mu \mathrm{g} / \mathrm{ml}$ \\
$3 \mathrm{~h}$ & $0.62-1.25 \mu \mathrm{g} / \mathrm{ml}$ & $0.31-0.62 \mu \mathrm{g} / \mathrm{ml}$ & $160-320 \mu \mathrm{g} / \mathrm{ml}$ \\
S. sanguis ATCC 10556 & & \\
$<1 \mathrm{~min}$ & $1.25-2.5 \mu \mathrm{g} / \mathrm{ml}$ & $0.62-1.25 \mu \mathrm{g} / \mathrm{ml}$ & $160-320 \mu \mathrm{g} / \mathrm{ml}$ \\
$1 \mathrm{~h}$ & $0.31-0.62 \mu \mathrm{g} / \mathrm{ml}$ & $0.15-0.31 \mu \mathrm{g} / \mathrm{ml}$ & $40-80 \mu \mathrm{g} / \mathrm{ml}$ \\
$3 \mathrm{~h}$ & $0.15-0.31 \mu \mathrm{g} / \mathrm{ml}$ & $0.15-0.31 \mu \mathrm{g} / \mathrm{ml}$ & $40-80 \mu \mathrm{gg} / \mathrm{ml}$ \\
C. albicans ATCC 1023 & & \\
$<1 \mathrm{~min}$ & $80-160 \mu \mathrm{g} / \mathrm{ml}$ & $320-640 \mu \mathrm{g} / \mathrm{ml}$ & $>1280 \mu \mathrm{g} / \mathrm{ml}$ \\
$1 \mathrm{~h}$ & $80-160 \mu \mathrm{g} / \mathrm{ml}$ & $>1280 \mu \mathrm{g} / \mathrm{ml}$ & $>1280 \mu \mathrm{g} / \mathrm{ml}$ \\
$3 \mathrm{~h}$ & $40-80 \mu \mathrm{g} / \mathrm{ml}$ & $>1280 \mu \mathrm{g} / \mathrm{ml}$ & $>1280 \mu \mathrm{g} / \mathrm{ml}$ \\
\hline
\end{tabular}

Irradiation with metal halide lamp, $\lambda 420-700 \mathrm{~nm}$, fluence $37 \mathrm{J.cm}{ }^{-2}$ 

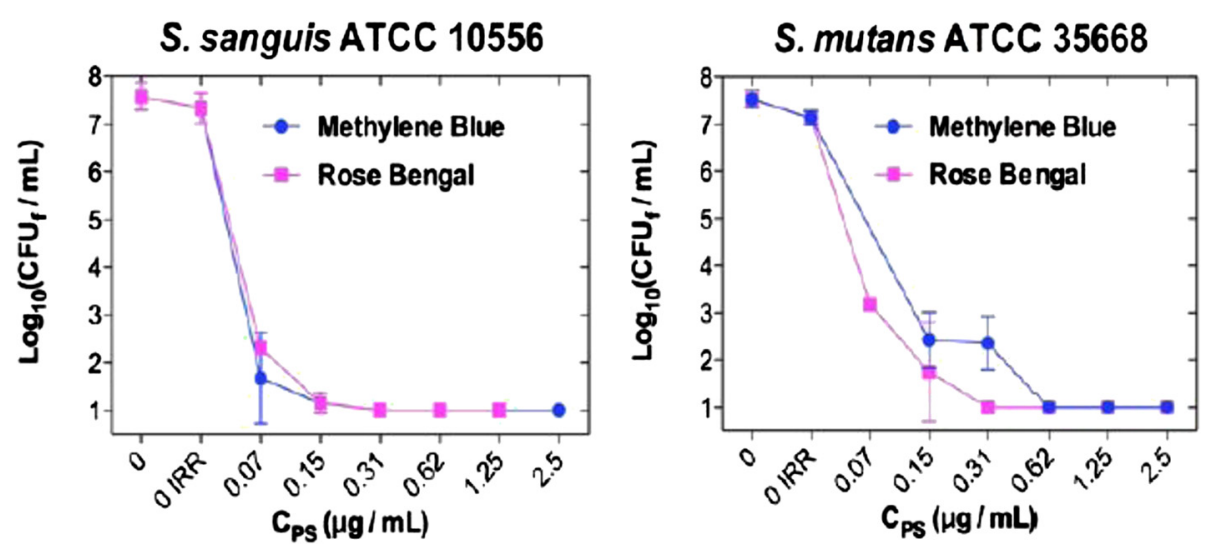

Fig. 1 Photodynamic effect of MB and RB on S. sanguis and S. mutans depending on their concentration (Incubation time with the PS $<1$ min and irradiation using a metal halide lamp with a fluence of $37 \mathrm{~J} / \mathrm{cm}^{2}$ )

Streptococcus spp than the other PSs studied, whereas MB was better for Candida spp. CUR always showed the lowest antimicrobial activity; this could be due to the fact that the higher peaks of the spectrum emission of the lamp correspond better to the absorptium spectra of RB and MB than CUR. Table 2 shows that compared with previous studies using aPDT with $\mathrm{MB}$, RB and CUR for S. mutans, our parameters seem to be more efficient, especially considering the percentage of bacterial growth inhibition of $99.9999 \%$. Regarding the antimicrobial effect of MB-PDT on the viability of S. mutans, Araujo et al. [33] needed $25 \mu \mathrm{g} / \mathrm{ml} \mathrm{MB}$ to reach $73 \%$ inhibition. Nevertheless, our results are not completely comparable because they used red light, which corresponds with the maximum spectrum absorbance of MB. Regarding RB, studies carried out by Costa et al. [34] show that the concentration

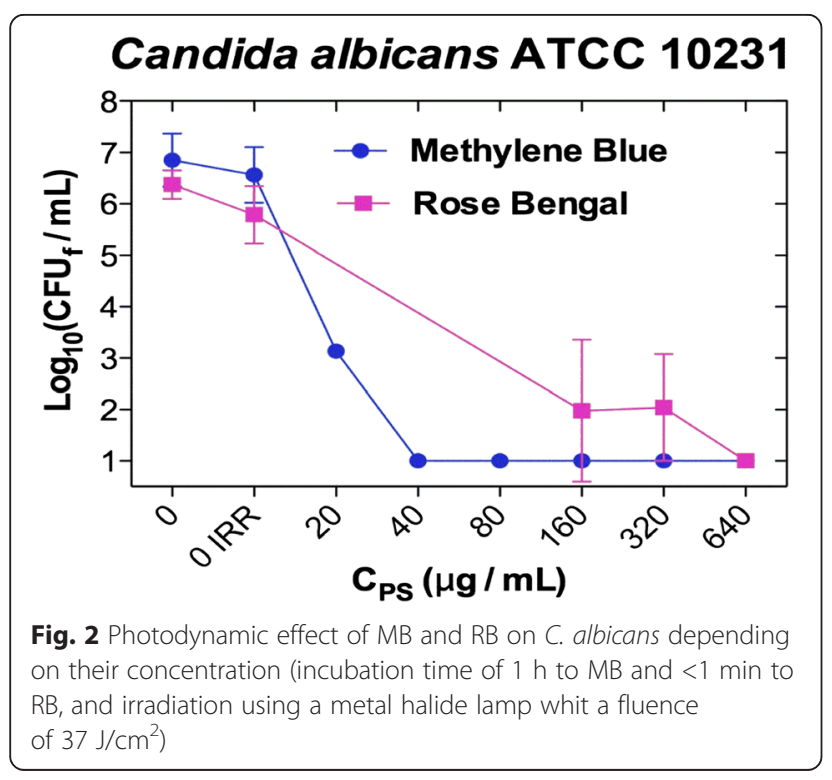

needed to attain $6.86 \log 10 \mathrm{CFU} / \mathrm{mL}$ reduction of $S$. mutans was $2.02 \mu \mathrm{g} / \mathrm{ml}$, using a LED lamp with $\lambda$ $440-460 \mathrm{~nm}$ and a fluence of $95 \mathrm{~J} / \mathrm{cm}^{2}$. Comparing to our results they needed higher concentrations of PS to reach a similar effect, perhaps because the $\lambda$ of their lamp was less convenient than ours to excite RB; another reason could be the use of distilled water as dissolvent, whereas they used phosphate-buffered saline because, based in the study of Nuñez et al. [35], a significant difference in the same aPDT experiment can be promoted only by the use of differents dissolvents.

According to this study, CUR needs much higher concentration than $\mathrm{RB}$ and $\mathrm{MB}$ to photoinactivate bacteria. This result agrees with those obtained by Araujo et al. [23] who, using a concentration of $1500 \mu \mathrm{g} / \mathrm{ml}$ and blue LEDs lamp ( $\lambda 450 \mathrm{~nm}$, fluence $5.7 \mathrm{~J} / \mathrm{cm}^{2}$ ), reached $60 \%$ inhibition of $S$. mutans in planktonic cultures. However, other studies obtained $95 \%$ reduction of S. mutans instead of 6 logs using only $0.73 \mu \mathrm{g} / \mathrm{ml}$ CUR, which could be explained by the higher fluence used $\left(72 \mathrm{~J} / \mathrm{cm}^{2}\right)$, the $\lambda$ of the lamp (blue light) and the lower percentage of bactericidal activity obtained.

Few studies compare the efficacy of different PSs to photoinactivate oral microorganisms. Rolim et al. [36] showed that $\mathrm{MB}$, toluidine blue ortho, malachite green, erythrosine, eosin and RB, using a red LEDs lamp for the former and a blue one for the later, were photoactive in vitro against $S$. mutans, but only toluidine blue reduced $99.9 \%$ of the microorganism. In this study, they also find a bactericidal effect of RB on S. mutans without light. Nevertheless, in our study no antimicrobial effects were observed when the strains were exposed either to the dyes or the light source separately.

Considering that the cariogenic potential of S. sanguis is deemed low compared to that of the S. mutans, the number of reports using aPDT to kill S. sanguis is lower than those of $S$. mutans. Chan et al. [37] demonstrated 
Table 2 Summary of the in vitro PDT studies using methylene blue, rose Bengal or curcumin on S. mutans, S. sanguis and C. albicans

\begin{tabular}{|c|c|c|c|c|c|}
\hline & PS & $\begin{array}{l}\text { Concentration } \\
(\mu \mathrm{g} / \mathrm{ml})\end{array}$ & $\begin{array}{l}\text { Inhibition } \\
\text { (\%) }\end{array}$ & $\begin{array}{l}\lambda \\
(n m)\end{array}$ & $\begin{array}{l}\text { Fluence } \\
\left(\mathrm{J} / \mathrm{cm}^{2}\right)\end{array}$ \\
\hline \multicolumn{6}{|l|}{ S. mutans } \\
\hline Araújo et al. [33] & MB & 25 & 73 & ND & ND \\
\hline Our study & $M B$ & 2.5 & 999.999 & $420-700$ & 37 \\
\hline Costa et al. [34] & RB & 2.02 & 999.999 & $440-460$ & 95 \\
\hline Our study & RB & 0,62 & 999.999 & $420-700$ & 37 \\
\hline Araújo et al. [23] & CUR & 1500 & 99.9 & 450 & 5.7 \\
\hline Paschoal et al. [44] & CUR & 1473.5 & 60 & 450 & 72 \\
\hline Manoil et al. [45] & CUR & 0.73 & $95 \%$ & $360-550$ & 542 \\
\hline Our study & CUR & 160 & 999.999 & $420-700$ & 37 \\
\hline \multicolumn{6}{|l|}{ S. sanguis } \\
\hline Chan et al. [37] & AM & 100 & 99-100 & 632.8 & 21.2 \\
\hline Our study & AM & 2.5 & 999.999 & $420-700$ & 37 \\
\hline Pereira et al. [32] & RB & 5 & 9.9 & 455 & 95 \\
\hline Our study & RB & 0.62 & 999.999 & $420-700$ & 37 \\
\hline Our study & CUR & 1500 & 999.999 & $420-700$ & 37 \\
\hline Mattiello et al. [46] & TB & 200 & 84.32 & 660 & 10 \\
\hline \multicolumn{6}{|l|}{ C. albicans } \\
\hline Souza et al. [15] & AM & 100 & 99.9 & 660 & 39,5 \\
\hline Peloi et al. [14] 4 & AM & 22,5 & 95,14 & 663 & 6 \\
\hline Souza et al. [16] & AM & 100 & 88,6 & 685 & 28 \\
\hline Our study & AM & 160 & 99.999 & $420-700$ & 37 \\
\hline Costa et al. [18] & RB & 23 & 9.9 & 455 & 95 \\
\hline $\begin{array}{l}\text { Demidova et al. } \\
\text { [47] }\end{array}$ & RB & 200 & 99,9999 & $525-555$ & 80 \\
\hline Our study & RB & $>1280$ & $<99.999$ & $\begin{array}{l}420- \\
700\end{array}$ & 37 \\
\hline Andrade et al. [26] & CUR & 7,3 & 89.5 & 455 & 5,28 \\
\hline Dovigo et al. [48] & CUR & 14,8 & 85 & $440-460$ & 18 \\
\hline Our study & CUR & $>2460$ & $<99.999$ & $420-700$ & 37 \\
\hline
\end{tabular}

PS photosentizer, $M B$ methylene blue, $R B$ rose bengal, $C U R$ curcumin, $T B$ toluidine blue ortho, ND no data

that PDT with $\mathrm{MB}$ was able to obtain a reduction of 99-100\% on cultures of S. sanguis. However, they used higher concentrations $(100 \mu \mathrm{g} / \mathrm{ml})$ than we used but lower fluence $\left(21.2 \mathrm{~J} / \mathrm{cm}^{2}\right)$ of a diode laser $(665 \mathrm{~nm})$. Pereira et al. [32] only obtained a $9.9 \%$ inhibition with $5 \mu \mathrm{g} / \mathrm{ml} \mathrm{RB}$ and they used a higher fluence. Therefore, our results show $\mathrm{MB}$ as the most efficient bactericidal PS for S. sanguis.

According to the present investigation, MB has better antifungal profile than RB and CUR. Other authors [14, 15,38 ], show that MB-aPDT is endowed with antifungal potential against C. albicans, whereas Costa et al. [18] show that $\mathrm{RB}$ only reach a $1,97 \log 10$ reduction in $C$. albicans.

Comparing the three PSs, the present study shows that MB is the most effective PS on C. albicans while RB was slightly superior for S. mutans. Dental caries result from interactions among different cariogenic microorganisms, so using or combining different PSs could improve the efficacy of aPDT. In this sense, the use of a white light lamp that covers all the absorption spectrum of most PSs can efficiently excite them, making PDT easier to perform and avoiding the necessity of using a lamp for each PS. However, a light source with an emission spectrum that corresponds to the maximum absorption spectrum of each PS theoretically determines a higher efficacy [39]. Red light sources (630-700 $\mathrm{nm}$ ) have been used extensively in PDT due to their relatively long wavelengths, which can effectively penetrate biological tissues and activates some of the most effective PSs, such as phenothiazines and porphyrins. Additionally, other studies have also shown that blue light (380-520 nm) is an attractive option for PDT, because blue light sources can be used in combination with many PSs, such as RB, eosin, erythrosine, and CUR to photoinactivate oral microorganisms [36]. For this reason, one limitation of our study is the use of the same lamp to photoactivate the three PSs, whose emission spectrum matches quite accurately with the maximum absorptium spectra of $\mathrm{RB}$ and MB but not with CUR. This could influence the bad results obtained with the later.

According to our data, the minimal bactericidal or fungicidal concentration was reduced in some experiments with a pre-irradiation incubation time of $1 \mathrm{~h}$. However, considering that the increase in the concentration was only of one or two dilutions, the difficulty to maintain therapeutic concentrations of the PS in the high flow conditions within the oral cavity (due to saliva and/or gingival crevicular fluid) for a long period of time [40] do not support the use of incubation time in the clinical setting. Andrade et al. [26] using CUR and Rezusta et al. [41] with hypericin concluded that none incubation time enhance the photoinactivation of planktonic cultures of C. albicans. Additionally, although the adverse effects of blood and saliva could be avoided with the help of dental dams, not pre-incubation time is more comfortable for the patients and more efficient for doctors.

\section{Conclusions}

The photodynamic efficacy of each PS varies according to the target microorganism. The combination of different PS and white light could be a promising approach to treat those infections caused by a combination of microorganisms, such as caries. 


\section{Materials and methods Chemicals}

Methylene Blue (MB) and Curcumin (CUR) were purchased from Sigma-Aldrich and Rose Bengal from Fluka. Sabouraud Dextrose Agar (SB) and Columbia Blood Agar (BA) were purchased from Oxoid.

\section{Microorganisms and growth conditions}

S. mutans ATCC 35668, S. sanguis ATCC 10556 and C. albicans ATCC 10231 strains were obtained from the American Type Culture Collection (ATCC; Rockville, MD).

McFarland scale is recommended for performance of susceptibility testing by CLSI [42] and EUCAST [43].

The yeasts were grown aerobically overnight in SB medium at $35{ }^{\circ} \mathrm{C}$. Stock inoculum suspensions were prepared in distilled water and adjusted to optical densities corresponding to 4.5 McFarland for five logs reduction assays. Cell viability was assessed counting the number of colony-forming units (CFU), developed on SB after an incubation period of $24 \mathrm{~h}$ at $35^{\circ} \mathrm{C}$.

S. mutans and $S$. sanguis were grown aerobically in BA medium at $35{ }^{\circ} \mathrm{C}$ for $48 \mathrm{~h}$. Stock inoculum suspensions were prepared in distilled water and adjusted to optical densities corresponding to 0.5 McFarland for six logs reduction assays. Cell viability was assessed counting the number of CFU, developed on BA after an incubation period of $48 \mathrm{~h}$ for $S$. mutans and $24 \mathrm{~h}$ for $S$. sanguis at $35^{\circ} \mathrm{C}$.

\section{Photosensitizer solutions}

Stock MB, RB and CUR solutions were prepared in distilled water and diluted either with bidistilled water to the desired concentration immediately prior to use. The concentrations used ranged from $0.1-12800 \mu \mathrm{g} / \mathrm{ml}$. All solutions were prepared and handled under lightrestricted conditions.

\section{Light source}

In order to cover the spectrum absorption of the 3 PSs (Fig. 3), MB, RB and CUR (maximal absorption $\lambda$ at 665 , 557 and $430 \mathrm{~nm}$ respectively), we used a metal halide lamp emitting at 420-700 nm (Fig. 4) with an irradiance of $90 \mathrm{~mW} / \mathrm{cm}^{2}$, being the specific irradiance at the maximal absorptium $\lambda$ of each PS : $292 \mu \mathrm{W} / \mathrm{cm}^{2}$ at $557 \mathrm{~nm}$, $300 \mu \mathrm{W} / \mathrm{cm}^{2}$ at $665 \mathrm{~nm}$ and $186 \mu \mathrm{W} / \mathrm{cm}^{2}$ at $430 \mathrm{~nm}$.

Microorganisms suspensions with the different PSs prepared into a 96 wells microtiter plate, with a well diameter of $6 \mathrm{~mm}$, were irradiated for $6 \mathrm{~min}$ and $51 \mathrm{~s}$ at a distance of $10 \mathrm{~cm}$. The light beam diameter was $21 \mathrm{~cm}$ and the
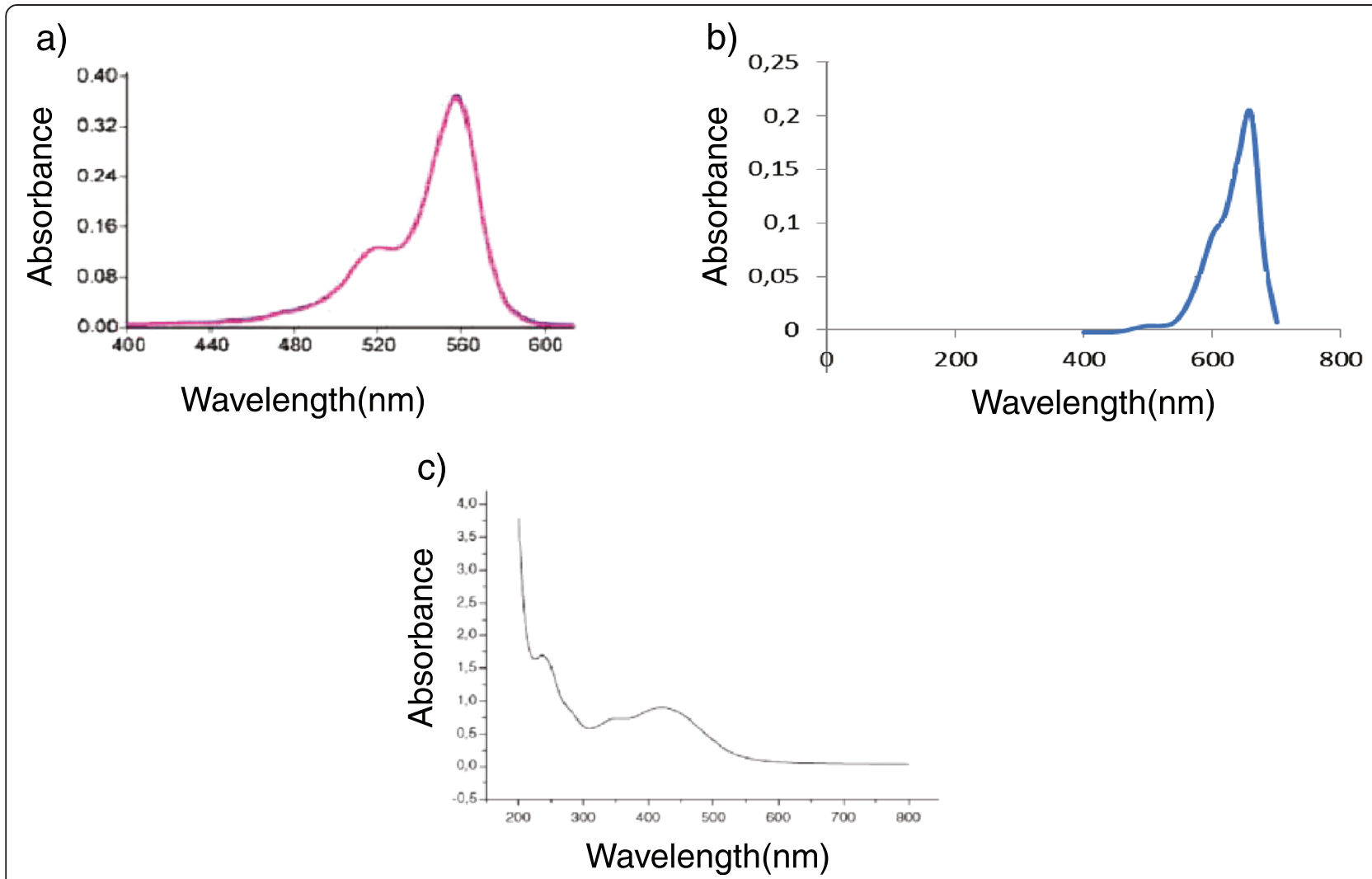

Fig. 3 Spectrum absorption of rose Bengal $\mathbf{a}$, methylene blue $\mathbf{b}$ and curcumin $\mathbf{c}$ 


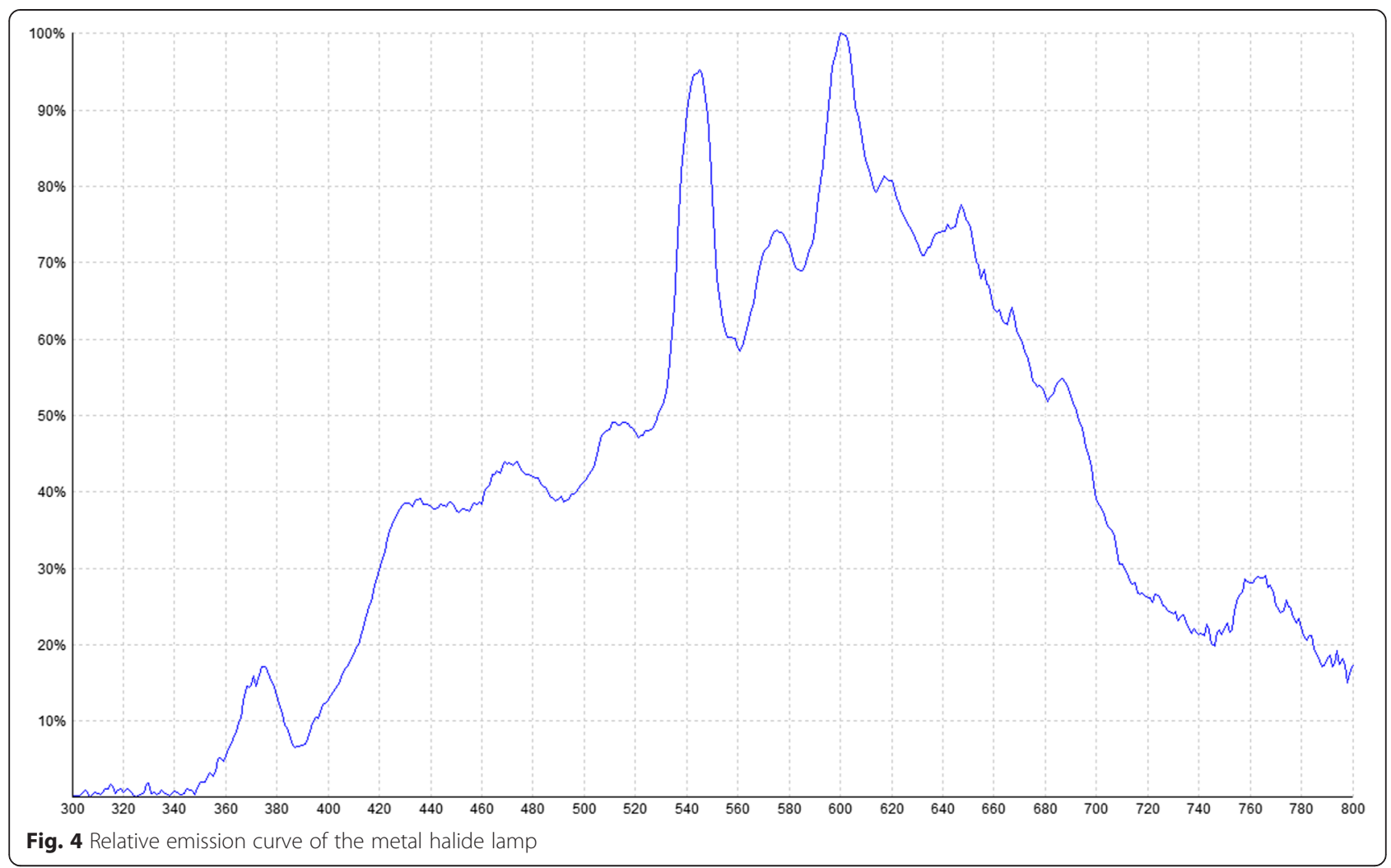

fluence used $37 \mathrm{~J} / \mathrm{cm}^{2}$. The effective light received on the dishes results from integrating the power of the lamp for all the effective wavelengths for each PS.

\section{Photodynamic treatments of microorganisms}

Suspensions with the desired McFarland value of every microorganism were prepared in bidistilled water. $90 \mu \mathrm{L}$ of these initial suspensions was dropped into different wells of a microtiter plate and $10 \mu \mathrm{L}$ of the different PS solutions were added. The final PS concentration in the experiments used ranged from $0.01-1280 \mu \mathrm{g} / \mathrm{ml}$. The plates were then maintained in the dark for different periods of time ( $<1 \mathrm{~min}, 1$ and $3 \mathrm{~h}$ ) to evaluate the influence of contact time with the PS on the outcome of the photodynamic treatments. Afterwards, microorganisms were subjected to illumination $\left(37 \mathrm{~J} / \mathrm{cm}^{2}\right)$.

Fungal and bacterial cultures grown under the same conditions with and without PS, either kept in the dark or illuminated, served as controls.

After photodynamic treatments, samples and controls were incubated at $35{ }^{\circ} \mathrm{C}$ for $24 \mathrm{~h}$, in case of C. albicans and S. sanguis experiments, and for $48 \mathrm{~h}$ in case of $S$. mutans. The antimicrobial effect was determined by counting the number of CFU per millilitre.

A criterion of $5 \log 10$ unit decrease from the starting inoculum was adopted to define fungicidal activity, and a more stringent criterion of $6 \log 10$ unit for bactericidal activity, due to the differences in cell size and mass between Candida spp and Streptococcus spp (the cell concentration of $C$. albicans used was 10 times lower $\left(>10^{5}\right)$ than that used for the two bacterial species $\left.\left(>10^{6}\right)\right)$.

All experiments were carried out at least five times.

\section{Abbreviations}

MB: Methylene blue; RB: Rose bengal; CUR: Curcumin; CFU: Colony forming units; PDT: Photodynamic therapy; aPDT: Antimicrobial photodynamic therapy; PS: Photosensitizer; SB: Sabouraud dextrose agar; BA: Columbia blood agar.

\section{Competing interests}

The authors declare that they have no competing interests.

\section{Authors' contributions}

PSL conceived of the study, conducted all experiments and drafted the manuscript. YG participated in the design of the study, in the interpretation of data for the work and she drafted the manuscript, the cover letter and the answers to the reviewer's reports. LPA and VLP conducted some experiments and helped to draft the manuscript. VPL is studying the photodynamic effect in co-cultures of $C$. albicans and S. mutans and she checked our results. She also revised the manuscript and contributed to the resolution of reviewer's reports. IGL has contributed to the interpretation of data for the work and to the resolution of biofilms questions and in the discussion of the final manuscript because she works with us in the project CTQ 2013-48767-C3-2-R from the Spanish Ministry of Science and Innovation studing the effect of photodynamic therapy on biofilms. MPPC participated in the design of the study, analyzed the data, performed the Figs. 1 and 2 and he revised the manuscript particularly the methodology and the materials. JAA performed the Figs. 3 and 4 and he wrote everything related light parameters both in the manuscript and in the answers to the reviewer's reports. MJR contributed to the design of the work, and revising and correcting it, particularly the background and the discussion. AR conceived of the study and drafted the manuscript. All authors read and approved the final manuscript. 


\section{Acknowledgements}

This study was supported by grants CTQ2013-48767-C3-2-R from the Spanish Ministry of Science and Innovation, Spain and European Regional Development Fund.

\section{Author details}

'Department of Microbiology, Hospital Universitario Miguel Servet, Zaragoza, Spain. ${ }^{2}$ Department of Dermatology, Hospital San Jorge, Huesca, Spain.

${ }^{3}$ Health Science Institute of Aragón, Zaragoza, Spain. ${ }^{4}$ Department of Applied Physics. Faculty of Science, University of Zaragoza, Zaragoza, Spain.

${ }^{5}$ Department of Microbiology, University of Sevilla, Sevilla, Spain.

${ }^{6}$ Department of Microbiology, University of Zaragoza, Zaragoza, Spain.

Received: 6 November 2014 Accepted: 21 September 2015

\section{Published online: 26 September 2015}

\section{References}

1. Vahabi S, Fekrazad R, Ayremlou S, Taheri S, Zangeneh N. The effect of antimicrobial photodynamic therapy with radachlorin and toluidine blue on Streptococcus mutans: an in vitro study. J Dent (Tehran). 2011;8(2):48-54.

2. Lima JP, de Melo MA S, Borges FM, Teixeira AH, Steiner-Oliveira C, Nobre Dos Santos M, et al. Evaluation of the antimicrobial effect of photodynamic antimicrobial therapy in an in situ model of dentine caries. Eur J Oral Sci. 2009;117(5):568-74.

3. Marsh PD. Microbiologic aspects of dental plaque and dental caries. Dent Clin North Am. 1999;43(4):599-614. v-vi.

4. Jenkinson HF. Adherence and accumulation of oral streptococci. Trends Microbiol. 1994;2(6):209-12.

5. Orasmo EMW, Otani C, Khouri S. In vitro AFM evaluation of Streptococcus mutans membrane exposed to two mouthwashes. JAPS. 2013;3:024-8.

6. Caufield PW, Dasanayake AP, Li Y, Pan Y, Hsu J, Hardin JM. Natural history of Streptococcus sanguinis in the oral cavity of infants: evidence for a discrete window of infectivity. Infect Immun. 2000;68(7):4018-23.

7. Metwalli KH, Khan SA, Krom BP, Jabra-Rizk MA. Streptococcus mutans, Candida albicans, and the human mouth: a sticky situation. PLoS Pathog. 2013;9(10):e1003616.

8. Falsetta ML, Klein MI, Colonne PM, Scott-Anne K, Gregoire S, Pai CH, et al. Symbiotic relationship between Streptococcus mutans and Candida albicans synergizes virulence of plaque biofilms in vivo. Infect Immun. 2014;82(5):1968-81.

9. Fontana CR, Abernethy AD, Som S, Ruggiero K, Doucette S, Marcantonio RC, et al. The antibacterial effect of photodynamic therapy in dental plaquederived biofilms. J Periodontal Res. 2009;44(6):751-9.

10. Ball AR, Tego GP. Emerging antimicrobial drug-discovery strategies: an evolving necessity. 1st ed. Cambridge: Cabi; 2012.

11. Kharkwal GB, Sharma SK, Huang YY, Dai T, Hamblin MR. Photodynamic therapy for infections: clinical applications. Lasers Surg Med. 2011;43(7):755-67.

12. Zanin IC, Gonçalves RB, Junior AB, Hope CK, Pratten J. Susceptibility of Streptococcus mutans biofilms to photodynamic therapy: an in vitro study. J Antimicrob Chemother. 2005;56(2):324-30.

13. Meisel P, Kocher T. Photodynamic therapy for periodontal diseases: state of the art. J Photochem Photobiol B. 2005;79(2):159-70.

14. Peloi LS, Soares RR, Biondo CE, Souza VR, Hioka N, Kimura E. Photodynamic effect of light-emitting diode light on cell growth inhibition induced by methylene blue. J Biosci. 2008;33(2):231-7.

15. Souza RC, Junqueira JC, Rossoni RD, Pereira CA, Munin E, Jorge AO. Comparison of the photodynamic fungicidal efficacy of methylene blue, toluidine blue, malachite green and low-power laser irradiation alone against Candida albicans. Lasers Med Sci. 2010;25(3):385-9.

16. de Souza SC, Junqueira JC, Balducci I, Koga-Ito CY, Munin E, Jorge AO. Photosensitization of different Candida species by low power laser light. J Photochem Photobiol B. 2006;83(1):34-8.

17. Munin E, Giroldo LM, Alves LP, Costa MS. Study of germ tube formation by Candida albicans after photodynamic antimicrobial chemotherapy (PACT). J Photochem Photobiol B. 2007;88(1):16-20.

18. Costa AC, Rasteiro VM, Pereira CA, Rossoni RD, Junqueira JC, Jorge AO. The effects of rose bengal- and erythrosine-mediated photodynamic therapy on Candida albicans. Mycoses. 2012;55(1):56-63.

19. Chui C, Aoki A, Takeuchi Y, Sasaki Y, Hiratsuka K, Abiko Y, et al. Antimicrobial effect of photodynamic therapy using high-power blue light-emitting diode and red-dye agent on Porphyromonas gingivalis. J Periodontal Res. 2013;48(6):696-705.

20. Bolean M, Paulino TP, Thedei G, Ciancaglini P. Photodynamic therapy with rose bengal induces GroEL expression in Streptococcus mutans. Photomed Laser Surg. 2010;28 Suppl 1:84-S7.

21. Freire F, Costa AC, Pereira CA, Beltrame Junior M, Junqueira JC, Jorge AO. Comparison of the effect of rose bengal- and eosin Y-mediated photodynamic inactivation on planktonic cells and biofilms of Candida albicans. Lasers Med Sci. 2014;29(3):949-55.

22. Guo Y, Rogelj S, Zhang P. Rose Bengal-decorated silica nanoparticles as photosensitizers for inactivation of gram-positive bacteria. Nanotechnology. 2010;21(6):065102.

23. Araújo NC, Fontana CR, Bagnato VS, Gerbi ME. Photodynamic effects of curcumin against cariogenic pathogens. Photomed Laser Surg. 2012;30(7):393-9.

24. Wang D, Hu J, Lv L, Xia X, Liu J, Li X. Enhanced inhibitory effect of curcumin via reactive oxygen species generation in human nasopharyngeal carcinoma cells following purple-light irradiation. Oncol Lett. 2013;6(1):81-5.

25. Kunnumakkara AB, Anand P, Aggarwal BB. Curcumin inhibits proliferation, invasion, angiogenesis and metastasis of different cancers through interaction with multiple cell signaling proteins. Cancer Lett. 2008;269(2):199-225.

26. Andrade MC, Ribeiro AP, Dovigo LN, Brunetti IL, Giampaolo ET, Bagnato VS, et al. Effect of different pre-irradiation times on curcumin-mediated photodynamic therapy against planktonic cultures and biofilms of Candida spp. Arch Oral Biol. 2013;58(2):200-10.

27. Garcia-Gomes AS, Curvelo JA, Soares RM, Ferreira-Pereira A. Curcumin acts synergistically with fluconazole to sensitize a clinical isolate of Candida albicans showing a MDR phenotype. Med Mycol. 2012;50(1):26-32.

28. Jackson Z, Meghii S, Macrobert A, Henderson B, Wilson M. Killing of the yeast and hyphal forms of Candida albicans using a light-activated antimicrobial agent. Lasers Med Sci. 1999;14(2):150-7.

29. Jori G, Fabris C, Soncin M, Ferro S, Coppellotti O, Dei D, et al. Photodynamic therapy in the treatment of microbial infections: basic principles and perspective applications. Lasers Surg Med. 2006;38(5):468-81.

30. O'Riordan K, Akilov OE, Hasan T. The potential for photodynamic therapy in the treatment of localized infections. Photodiagnosis Photodyn Ther. 2005;2(4):247-62.

31. Lambrechts SA, Aalders MC, Van Marle J. Mechanistic study of the photodynamic inactivation of Candida albicans by a cationic porphyrin. Antimicrob Agents Chemother. 2005;49(5):2026-34.

32. Pereira CA, Costa AC, Carreira CM, Junqueira JC, Jorge AO. Photodynamic inactivation of Streptococcus mutans and Streptococcus sanguinis biofilms in vitro. Lasers Med Sci. 2013;28(3):859-64.

33. Araújo PV, Teixeira Kl, Lanza LD, Cortes ME, Poletto LT. In vitro lethal photosensitization of S. mutans using methylene blue and toluidine blue $\mathrm{O}$ as photosensitizers. Acta Odontol Latinoam. 2009;22(2):93-7.

34. Costa AC, Chibebe Junior J, Pereira CA, Machado AK, Beltrame Junior M, Junqueira JC, et al. Susceptibility of planktonic cultures of Streptococcus mutans to photodynamic therapy with a light-emitting diode. Braz Oral Res. 2010;24(4):413-8.

35. Núñez SC, Garcez AS, Kato IT, Yoshimura TM, Gomes L, Baptista MS, et al. Effects of ionic strength on the antimicrobial photodynamic efficiency of methylene blue. Photochem Photobiol Sci. 2014;13(3):595-602.

36. Rolim JP, De-Melo MA, Guedes SF, Albuquerque-Filho FB, De Souza JR, Nogueira NA, et al. The antimicrobial activity of photodynamic therapy against Streptococcus mutans using different photosensitizers. J Photochem Photobiol B. 2012;106:40-6.

37. Chan Y, Lai CH. Bactericidal effects of different laser wavelengths on periodontopathic germs in photodynamic therapy. Lasers Med Sci. 2003;18(1):51-5.

38. Pupo YM, Gomes GM, Santos EB, Chaves L, Michel MD, Kozlowski VA, et al. Susceptibility of Candida albicans to photodynamic therapy using methylene blue and toluidine blue as photosensitizing dyes. Acta Odontol Latinoam. 2011;24(2):188-92.

39. Calzavara-Pinton PG, Venturini M, Sala R. Photodynamic therapy: update 2006. Part 1: Photochemistry and photobiology. J Eur Acad Dermatol Venereol. 2007;21(3):293-302.

40. Wilson M. Lethal photosensitisation of oral bacteria and its potential application in the photodynamic therapy of oral infections. Photochem Photobiol Sci. 2004;3(5):412-8. 
41. Rezusta A, López-Chicón P, Paz-Cristobal MP, Alemany-Ribes M, Royo-Díez $D$, Agut $M$, et al. In vitro fungicidal photodynamic effect of hypericin on Candida species. Photochem Photobiol. 2012;88(3):613-9.

42. Clinical and Laboratory Standards Institute. Performance Standards for Antimicrobial Susceptibility Testing: 520 Q6. Twenty-Fourth Informational Supplement. CLSI document M 100-S24 (ISBN 1-56238-897-S (Print); ISBN 1 56238-898-3 (Electronic)). Wayne, PA: Clinical and Laboratory Standards Institute; 2014

43. The European Committee on Antimicrobial Susceptibility Testing. Breakpoint tables for interpretation of MICs and zone diameters. Version 4.0, 2014. http://www.eucast.org.

44. Paschoal MA, Tonon CC, Spolidório DM, Bagnato VS, Giusti JS, Santos-Pinto L. Photodynamic potential of curcumin and blue LED against Streptococcus mutans in a planktonic culture. Photodiagnosis Photodyn Ther. 2013;10(3):313-9.

45. Manoil D, Filieri A, Gameiro C, Lange N, Schrenzel J, Wataha JC, et al. Flow cytometric assessment of Streptococcus mutans viability after exposure to blue light-activated curcumin. Photodiagnosis Photodyn Ther. 2014;11(3):372-9.

46. Mattiello FD, Coelho AA, Martins OP, Mattiello RD, Ferrão Júnior JP. In vitro effect of photodynamic therapy on Aggregatibacter actinomycetemcomitans and Streptococcus sanguinis. Braz Dent J. 2011;22(5):398-403.

47. Demidova TN, Hamblin MR. Effect of cell-photosensitizer binding and cell density on microbial photoinactivation. Antimicrob Agents Chemother. 2005;49(6):2329-35.

48. Dovigo LN, Pavarina AC, Carmello JC, Machado AL, Brunetti IL, Bagnato VS. Susceptibility of clinical isolates of Candida to photodynamic effects of curcumin. Lasers Surg Med. 2011;43(9):927-34.

\section{Submit your next manuscript to BioMed Central and take full advantage of:}

- Convenient online submission

- Thorough peer review

- No space constraints or color figure charges

- Immediate publication on acceptance

- Inclusion in PubMed, CAS, Scopus and Google Scholar

- Research which is freely available for redistribution 